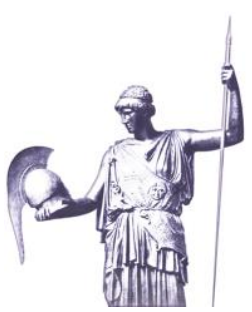

\title{
Migrants, Housewives, Warriors or Sex Slaves: AQ's and the Islamic State's Perspectives on Women
}

\section{Andrea Sjøberg Aasgaard}

Danish Institute for International Studies, http://www.diis.dk

\begin{abstract}
Why do young Muslim women from the whole world join the Islamic State (IS) in Syria and Iraq, despite the fact that the group is notorious for conducting terrible sexual violations against women? Through comparing how al-Qaeda (AQ) and IS are positioning women in their ideological literature, this article sheds light on IS' appeal to women. This is interesting, as $A Q$ in a historical perspective only attracted a handful of European women to physically join the group. The comparison highlights that $\mathrm{AQ}$ and IS position women in different ways: as housewives, migrants, warriors and sex slaves. Both groups' ideologies agree that a woman's primarily role is to be a housewife and mother, and exclude in principle women from the battlefield. However, only IS is emphasizing that Muslim women have a right and duty to migrate to its territory. Through using ideological arguments in its literature, IS convinces its supporters that it is a religious duty to enslave women the group defines as idolaters. For this reason, IS' brutality against non-Muslim women will not discourage its female supporters from joining the group.
\end{abstract}

Keywords: Islamic State, AQ, women, migrants, sex slaves, house wives, warriors.

\section{Introduction}

Although the global media report about terrible sexual violations against women committed by the so-called Islamic State (IS) in Iraq and Syria, young women from the whole world are travelling to these countries to join the group. After their arrival most women marry an IS fighter and spend their time as housewives. Never in a historical perspective have so many Muslim women, 
originally from Europe, travelled to the Middle East to join a militant Islamist group. In order to understand why IS as a movement attracts European women to join the group, while we at the same time hear terrible stories about IS' sex slaves, I will in this article analyze how IS positions women in their ideological literature. As AQ historically has recruited only a handful of European women, it is interesting to analyze the differences and similarities between the two movements' perspectives on women. I use magazines and ideological writings, published by IS and AQ. I will especially focus on Inspire, a magazine which is closely connected to $\mathrm{AQ}$ in the Arabian Peninsula, and then the magazine Risalah, which at the time of publication was connected to AQ's affiliation in Syria, the Nusrah-front. The Nusrah-front later broke this affiliation and changed name to Jabhat Fateh al-Sham. Lastly, I focus on IS' magazine Dabiq. I will especially focus on the four different roles IS and $A Q$ ascribe to women in their literature. These roles are as migrants, housewives, warriors or sex slaves.

As a point of departure, it is important to mention that media often describe the women travelling to Syria to join IS as "jihadi-brides," "brainwashed" and lured. This gives a simplified picture of women's motivation to join the organization and fits with a Western stereotypical picture of the oppressed Muslim woman. Although I will not look closer at the women's motivations in this article, it is essential to note that women always have played an active role in militant Islamist groups in the Middle East.

Historical examples of Muslim women participating in war go back to the time of Mohammed and his successors. For instance, Mohammed's wife Aisha led the so-called "Battle of the Camel" and his granddaughter Zaynab Bint Ali fought in the battle of Karbala. ${ }^{1}$ Women fought with Mohammed and his successors through leading male fighters, encouraging men to fight or through providing medical care. ${ }^{2}$ In the last decade, women have obtained a new role in militant Islamist groups, especially through committing suicide attacks. We have seen this especially in Palestine, Chechnya and Iraq.

It is also not new that women leave Europe to join militant Islamist groups in the Middle East. A handful of European women were recruited during the mid-2000s to join AQ in Iraq. The most famous example is the Belgian convert, Muriel Degauque, who conducted a suicide attack in Iraq in November 2005. Less known is that towards the end of the 2000s, hundreds of Germans, including a significant amount of women, emigrated to Waziristan, the border area between Afghanistan and Pakistan to participate in the conflict in Afghani-

Farhana Ali, "Rocking the Cradle to Rocking the World: The Role of Muslim Female Fighters," Journal of International Women's Studies 8, no. 1 (11 January 2013): 2135.

2 David Cook, "Women Fighting in Jihad?" Studies in Conflict \& Terrorism 28, no. 5 (1 September 2005), 375. 
stan and at the same time establish a colony. ${ }^{3}$ In this colony whole families lived and fulfilled their dreams about a better Islamic society. However, many were disappointed and in 2012 there were several media reports telling that these people returned to Germany. ${ }^{4}$

\section{Women as Migrants}

The first role IS ascribes to women in its literature is as migrants. IS has launched a comprehensive campaign to encourage women to conduct hijrah migration to its territory. In AQ's literature, there is a continuous theme that women should encourage the man to conduct hijrah and jihad, armed combat for the Sake of God, and not prevent his travel. However, she shall herself remain at home.

On July $1^{\text {st }}, 2014$, a speech of the IS' leader Abu Bakr al-Baghdadi was broadcast publicly. In this speech he encouraged Muslims from the whole world to conduct hijrah, i.e. to emigrate to the territories of the Islamic State. He said it was a duty. On social media, English-speaking women in the IS territory use the term "muhajirah," the Arabic word for migrant, about themselves. They say that they conducted hijrah to the Islamic State, something which has an important symbolical meaning for IS in its ideology. Hijrah also indicates the travel, which Mohammed and his companions conducted from Mecca to Medina in the year of 622. Muslims perceive hijrah as a turning point both for the development of Islam and for the world history. In this context, their use of the word muhajirah shows symbolically that the women perceive themselves to be essential for the future of Islam, since they emigrated to the IS territory to contribute to rebuilding the Islamic Caliphate.

In order to recruit women, IS has revolutionized jihadi organizations' use of propaganda directed towards women. The propaganda campaign is to some extent taking place in IS' own ideological writings. However, it especially takes place on social media, for instance on Tumblr and Twitter. From the $7^{\text {th }}$ issue of the IS' propaganda magazine Dabiq, there is an own section called "To our Sisters." This section discusses female migration and the life of women in the IS' territory. For instance, Hayat Boumeddiene, widow of Amedy Coulibaly, who killed four hostages during the attacks in a Paris Jewish Kosher shop in 2015, tells about her migration to the IS' territory in Syria. ${ }^{5}$ She tells about how pleased she is to live in the Caliphate. In 2014, the first blogs were written by

3 Ann-Sophie Hemmingsen, "Jeg En Stat Mig Bygge Vil," in Terrorisme Og Trusselsvurderinger, ed. Lars Erslev Andersen (København: Dansk Institut for Internationale Studier, 2014).

4 Özlem Gezer and Holger Stark, "Disillusioned German Islamists Returning Home to Germany," Spiegel Online, July 18, 2012, available at http://www.spiegel.de/ international/world/disillusioned-german-islamists-returning-home-to-germany-a844799.html (accessed March 23, 2016).

5 "A Brief Interview with Umm Basir Al-Muhajirah," Dabiq, no. 7 (February 2015): 5051. 
women, who allegedly live in the IS' territory. One example is the now blocked blog "Diary of a Muhajirah," where a woman allegedly from Malaysia tells about how women can travel to Syria, what they need to bring and she answers the readers' questions. The blog glorified the life under IS. In addition, many women claiming to live in the IS territory are present on Twitter, where they give a picture of their new life. In an attempt to prevent IS' recruitment on social media, Twitter is trying to block the women's accounts. However, new accounts always pop up again. Encrypted chat services, such as Telegram, are therefore playing increasingly important roles. Through this channel women in Europe are getting in touch with people in the IS' territory, where they receive information about how to travel to the area. Allegedly, a large group of European women is gathering daily in a house in Raqqa, where through Internet they attempt to recruit women.

In AQ's literature, the topic of women as migrants is almost absent. None of $A Q$ 's Inspire magazines discuss women as migrants. This is despite the fact that the magazines contain interviews with men, who have conducted hijrah for instance from Europe to Yemen and who encourage other men to emigrate. AQ emphasizes in their written material that jihad, armed battle and hijrah are primarily for men. However, as previously mentioned, a handful of women travelled from Europe to Iraq in the mid-2000s to join AQ. With the exception of the Belgian suicide bomber, Muriel Degauque, the details around these people's travels are unknown. In AQ's female magazine al-Shamikha from 2011, a widow after a Jihadi-fighter tells that she and her children did not travel with her husband to the war. She argued that it is impossible to bring children and women before the husband knows whether it is possible for them to travel. ${ }^{6}$ There is only one article about female migrants in AQ's magazines. This is in the magazine al-Risalah from 2015, which at the time of publication belonged to $A Q$ 's Syrian affiliation, the Nusrah-front.

Um Asiya Muhajirah writes about her hijrah from England to Bilad as-Sham. ${ }^{7}$ This term, as-Sham, in general is used to describe greater Syria and also includes parts of Jordan and Lebanon. The woman tells that she is a convert, widow after a martyr and the mother of three children. She explains that she emigrated to "as-Sham" to live together with Muslims, and to distance herself and her family from the infidels, "kuffar." One of the reasons why the Nusrahfront published this article was because they wanted to compete with IS about attracting male supporters. The article further shows the differences between IS and AQ. The woman discussed in the magazine emigrated to as-Sham. This does not necessarily mean Syria. She says it was because she wanted to live among Muslims. This shows that the Nusrah-front, in contrast to IS, does not have anything to offer women. There are strong indications that the Nusrahfront does not want women to join the group in Syria. There is no structure to

6 "Interview with a Fighter's Wife - 'The Lofty Woman'," Al-Shamikha 1 (2011).

Umm Asiya Muhajirah, "Hijra - My Story," Al-Risalah 1 (July 2015). 
host women or children, and women do not have a function in the insurgency war the Nusrah-front is conducting. Marriages will make the men attached to an area. This will make the war the Nusrah-front is conducting against Assad's regime more difficult. While since 2013 a large amount of women from the whole world have travelled to Syria to become a part of IS, there are no famous examples of women, who have travelled to Syria and other countries to join AQ affiliated groups the last years.

IS' campaign to recruit women has given results. Different estimates show that at least 10 per cent of the people travelling to join IS in Syria and Iraq from Western countries are women. This applies for instance to Scandinavia. From some countries, such as France and England, the numbers are higher. The women have travelled either with their husbands, another family member or a friend and several have brought their young children.

Women's roles as migrants are being positioned differently by IS and AQ. IS wants women to immigrate to their territory and spend many resources to achieve this goal. If women immigrate to the IS' territory, they have the possibility to contribute building a new Utopian society, the new Islamic Caliphate. This has been a dream for many Muslims since the end of the Islamic Golden Age in the $13^{\text {th }}$ century. Neither in Syria nor in other countries AQ is paying attention to women's role as migrants. Foreign women do not have any function in the Nusrah-front's territory in Syria. The role IS is attributing to women should not be underestimated in order to understand why IS is able to attract European women. For the first time in centuries, women have the possibility to play an important role to achieve the dream about building a caliphate.

\section{Women as Housewives}

Although $\mathrm{AQ}$ does not encourage women to immigrate to its territory, women are given an important role to achieve the organization's goal: as a virtuous housewife, who encourages and supports her husband to participate in jihad and who raises her children well, so that they in the future will fight for the cause of God. This view is shared by IS. The ideological works of IS and AQ show that both organizations claim that women primarily should play a role in the house as a good housewife. Women do not necessarily agree about this role, and the role of women in AQ has during the last decades been a topic of discussion in the organization.

Leading $\mathrm{AQ}$ clerks have discussed the role of the women several times. In a fatwa, a religious declaration from 1996, Bin Laden is emphasizing that women play an important role as supporters, facilitators and, not the least, when they encourage their men and sons to conduct jihad.

Bin Laden writes:

Our women had set a tremendous example of generosity in the cause of Allah; they motivated and encouraged their sons, brothers and husbands to 
fight-in the cause of Allah - in Afghanistan, Bosnia-Herzegovina, Chechenia and in other countries. ${ }^{8}$

In 2008, Ayman al-Zawahiri, AQ's present leader, said in a radiobroadcast that the role of women in jihad is limited to taking care of the home, and that women do not play a role in the global jihad. ${ }^{9}$ Rather, he claimed that the successful battle depends on non-military support from women, for instance through encouraging family members to participate in battles, as mothers of the new generation and as wives of the male fighters. Female AQ supporters disagreed with al-Zawahiri's perception that the role of women was limited to the house. Lengthy discussions about his statement followed on Jihadi internet fora. ${ }^{10}$ Female jihadi-supporters were disappointed and hurt that they were not allowed to fight in the same way as the men. This shows an initial women's liberation movement in $A Q$, where the younger generation of women disagreed with the older generation of clerks in the movement. As a reaction to the disagreements, al-Zawahiri's wife, Umayma Hassan Ahmed Muhammad Hassan published in 2009 an open letter to the Muslim sisters, where she supported her husbands' view that women's main role is to be good wives, support their husbands and to raise the new generations of warriors. ${ }^{11}$ However, Umayma also answered directly that women can participate in battles, even in martyr operations. In June 2012, Umayma Hassan published a new letter, where she appealed to the Muslim sisters after the revolutions in the Middle East. She recommends the "sisters" to raise their sons to love jihad and martyrdom without mentioning fighting.

This perspective on the women's role is continuously repeated in newer works by $A Q$ and is being discussed several times in the magazine Inspire. Again, women's role is reduced to sending their husbands and sons to conduct jihad for the global Muslim society, the Ummah. The examples show that the role of the women is an important topic of discussion for AQ. Despite the debates, there is no doubt that the role of the women primarily is to be at home.

IS' ideological works show that the movement has the same perspective on the role of women as $A Q$. Their role is limited to the home, through being a good wife and a good mother. In the $12^{\text {th }}$ issue of Dabiq, Umm Summayah alMuhajirah writes that women conduct jihad, when she patiently waits for her

8 “Bin Laden's Fatwa," PBS NewsHour, available at http://www.pbs.org/newshour/ updates/military-july-dec96-fatwa_1996/ (accessed 29 March 2016).

9 Mia Bloom, Bombshell: The Many Faces of Women Terrorists (Toronto: Penguin Canada, 2011); Ann-Sophie Hemmingsen, "Kønskamp i Al-Qaida," Kvinden Og Samfundet 127, no. 1 (May 2011).

10 Hemmingsen, "Kønskamp i Al-Qaida."

11 Christopher Dickey, "The Shadowland Journal: Zawahiri's Wife's Letter," available at http://christopherdickey.blogspot.com/2010/01/zawahiris-wifes-letter.html (accessed 23 March 2016). 
husband to return from the war, prays for him and raises his children. ${ }^{12} \mathrm{~A}$ woman can only fight if she herself is being attacked. Al-Muhajirah emphasizes that the role of women is to contribute to building the new Ummah through producing men and sending them to war. The article argues that this is just as important as actively participating in war. It further states that a woman's weapon is good behavior and knowledge about religion. In order to have enough religious knowledge to be able to raise the children in a suitable manner, Dabiq recommends that women join one of the many courses offered by IS about the Islamic Jurisprudence, Sharia.

On social media women describe the life as housewives in the IS' territory. When women arrive to the territory, they are placed in an all-female residence house, called "al-maqqar." It is expected that they marry an IS-fighter. After they have been married, they spend their daily life making food, learning Arabic and being together with other migrants. A woman is only allowed to leave her home, if she is together with her protector, a Mahram, a male relative or her husband. In an article in Dabiq 13, IS explains that if the woman should be widowed, she has to fulfill the mourning period, named Iddah, lasting four months and ten days. ${ }^{13}$ When the Iddah period has passed, it is expected that she should end her time of grieving. It is written indirectly that she is supposed to remarry.

The role of women is being discussed in the document "Women in the Islamic State," which was published on Jihadi internet fora in January $2015 .{ }^{14}$ The manifest states that it is not an official document of IS, but that it is made by supporters in al-Khanassa brigade. This is the name of IS all-female morality police. The document emphasizes that the role of women lies primarily in the home, which starts when she marries. Marriages are allowed after a girl is nineyears old. As it is necessary to have some knowledge to be a good mother, the document is introducing mandatory education for girls between seven and 15years old. There are only a few exceptions where women are allowed to play a role outside the home: if she is studying theology, if she is a female doctor or teacher, or if a fatwa is issued, allowing women to participate in Jihad. This is only allowed if there are not enough men to defend the country against the attack of the enemy. Interestingly, the document suggests a system for taking care of the children, if the mother has to work.

IS and AQ share the perspective about a woman's role as a housewife. Both believe that the primary task of women is to be at home, marry, give birth to children and raise their sons to fight for the sake of Allah. She also needs to have a great knowledge about religion, as she is responsible for passing on this

12 Umm Summayyah al-Muhajirah, "Two, Three or Four," Dabiq (12 November 2015): 19-22.

13 "Advice on Ihdad," Dabiq (13 January 2016): 24-26.

14 Charlie Winter, Women of the Islamic State (London: Quilliam Foundation, February 2015), available at https://www.quilliamfoundation.org/wp/wp-content/uploads/ publications/free/women-of-the-islamic-state3.pdf, accessed March 29, 2016. 
knowledge to her children. In this way they will be willing to use weapons to promote their religion.

\section{Female Warriors}

Occasionally women in the IS' territory publish photos of themselves on social media with a Kalashnikov in their hands. This gives a misleading picture. As the last section showed, women in IS have a limited role in fighting. AQ's ideology also excludes women from participating in operative fighting. However, there are historical exceptions.

Although women do not play a role in operative combat in IS, non-married women work in the all-female brigade al-Ketibet al-Khanassa, a part of IS' morality police al-Hisbah. This occurs in big cities such as Raqqa in Syria. The name al-Khanassa is not random. Al-Khanassa was an Arabic poet in the 7th century, who became a Muslim. In her poems she glorified the death of her brother in battle and encouraged all her sons to fight Jihad. When they were killed, she stated that she would not mourn, but celebrate their martyrdom. The women in the morality police receive one month of training, for instance to learn handling weapons. Interestingly, this brigade is not being discussed in the ideological literature of IS. According to statements to media from former female members of the group, its task is to secure that the women in Raqqa cover in public, that they do not use high-heeled shoes and that they are in the company of a man. It is also being reported that they have a special role to be guardian over new women arriving to the territory.

Although AQ's ideology excludes women from operative combat, there are examples of local adjustments. During the command of AQ's leader in Iraq, Abu Mus'ab al-Zarqawi, women started to conduct suicide attacks. The example is interesting, because AQ in Iraq was the predecessor to today's IS. Women conducted suicide attacks for AQ between 2005 and 2010, where most of the attacks were conducted in $2008 .^{15}$ At this time, one sixth of all the attacks were conducted by women. A review of the women's biographies shows that many of them were widows of killed AQ fighters in Iraq. ${ }^{16}$ Their wish for revenge, economic difficulties or traumas were likely reasons for their recruitment.

There are several explanations for why AQ in Iraq allowed female suicide bombers, even though that disputes the group's ideology. An explanation can be found with AQ's former leader in Iraq, al-Zarqawi, who stated that "War has broken out ... if you (Muslim men) are not going to be chivalrous knights in this

15 Jessica Davis, "Evolution of the Global Jihad: Female Suicide Bombers in Iraq," Studies in Conflict \& Terrorism 36, no. 4 (12 March 2013): 279-91; Mohammed Hafez, "Martyrdom Mythology in Iraq: How Jihadists Frame Suicide Terrorism in Videos and Biographies," Terrorism and Political Violence 19, no. 1 (January 2007): 95-115; Anne Speckhard, "Female Suicide Bombers in Iraq," Democracy and Security 5, no. 1 (16 March 2009): 19-50.

16 Speckhard, "Female Suicide Bombers in Iraq." 
war (fursan al-harb), make way for women to wage it. ... Yes, by God, men have lost their manhood." 17

This could have been a way to encourage men who had not yet taken up arms to fight. It is also important to mention that 2008 was the top year for employment of female suicide bombers in Iraq. This was two years after American bombs killed al-Zarqawi, and the movement was facing several challenges. Its new leader, Abu Omar al-Baghdadi, who is not the same person as the present IS' leader, attempted but failed to continue al-Zarqawi's state building project. The group faced economic difficulties, and foreign fighters who previously had conducted several suicide attacks had stopped arriving to the territory due to a better control of the Syrian-Iraqi border. In addition to this, stronger measures were taken to counter AQ's fighters and suicide bombers in Iraq. Under these conditions, it became easier for women to conduct suicide attacks, as women traditionally were not under suspicion. Women were never introduced into the leadership structure of $A Q .{ }^{18}$ After 2010, there are no examples of female suicide bombers in Iraq. The explanations are complex and must be seen in relation to a changing nature of the conflict. This was caused by the gradual reduction of US presence in the country that formally ended in 2011.

IS in Syria and Iraq, which arises from AQ in Iraq, has not employed women as suicide bombers. It is necessary to mention that there are exceptions in other IS' provinces. Women are conducting suicide attacks for Boko Haram in Nigeria, which now has declared their affiliation to IS. The reason why IS in Syria and Iraq does not use female suicide bombers is likely that the primary role of women in IS is to contribute to building the new caliphate by raising the new generation of children. Both social media and interviews in media show that foreign fighters are frustrated due to a lack of women. Marriages between foreign fighters and Syrians are occurring. It is reported that Syrian women are often forced into these marriages. ${ }^{19}$ IS wishes that foreign fighters marry Syrians to mix with the local population and to get a local affiliation to the area. European foreign fighters in Syria are however preferring to marry European women, something which partially explain IS' extensive recruitment of foreign women. As the number of foreign women is so low, women will contribute more to build the caliphate as a whole through marrying an IS fighter and to give birth to his child, rather than dying in armed battle.

17 Nelly Lahoud, "The Neglected Sex: The Jihadis' Exclusion of Women from Jihad," Terrorism and Political Violence 26, no. 5 (20 October 2014): 780-802.

18 Margaret Gonzalez-Perez, "Palestine, Iraq, Pakistan, and Afghanistan: Internationalization and Localization," Journal of Postcolonial Cultures and Societies 4, no. 1 (2013): 113-49.

19 Abu Mohammed, "Ghost of Marriage from ISIS Militants Frightens Women ... Raqqa Is Being Slaughtered Silently," February 16, 2015, available at http://www.raqqasl.co/en/?p=576 (accessed March 29, 2016). 
Although IS does not employ female suicide bombers, they acknowledge women who conduct this. An interesting example is the San Bernardino attack in California in the US. The IS magazine Dabiq glorifies Syed Rizwan Farook and his wife, Tashfeen Malik, who conducted the attack which killed 14 people. ${ }^{20}$ Dabiq tells that the attack was unique, because Malik conducted it together with his wife, despite that Jihad is not mandatory for her. The magazine argues that the wife did not wish to lose the possibility for shahadah, to become a martyr. Despite that the wife from other sources is described as the driving force behind the attack, Dabiq reduces her role to a person following her husband.

The ideological writings of $A Q$ also glorify women who have taken up arms for the sake of Allah. They use this as an appeal to Muslim men to do the same. For instance, the magazine Inspire mentions the American convert LaRose, nick named "Jihad Jane," who was arrested in 2009 and accused of planning to assassinate the Swedish artist Lars Vilks. The magazine also mentions the British woman Roshonara Choudhry who attacked the British Member of Parliament Stephen Timms in 2010. Choudhry is mentioned in the fourth publication of the magazine Inspire as an appeal to Muslim men:

A woman has shown to the Ummah's men the path of jihad! A woman my brothers! Shame on all the men for sitting on their hands while one of our women has taken up the individual jihad! She felt the need to do it simply because our men gave all too many excuses to refrain from it. ${ }^{21}$

Despite that women are essentially excluded from fighting, both by $A Q$ and IS, different needs can open up for local adjustments. This is especially apparent with IS predecessor, AQ in Iraq, where women played an important role as suicide bombers. AQ does not condemn women who conduct attacks on their own. However, they use it in their ideological writings as a call for men to do the same. Presently women can better fulfill the goal of the caliphate through being housewives and giving birth to new citizens, rather than being fighters. Although IS does not wish that women should fight, the example with Tashfeen Malik shows that they acknowledge women who take up arms to advance the case of the Ummah. It is therefore likely-should the needs of IS change in the future - that they will be willing to allow women to participate in combat.

\section{Women as Sex Slaves}

IS has become notorious for enslaving women they define as idolaters and infidels as sex slaves. This has especially hurt the Kurdish minority group, the Yazidis. There is no similar example from AQ, neither from an ideological perspective or historical examples. The topic is totally absent in the ideological

20 "Foreword," Dabiq (13 January 2016): 3-4.

21 Muhammed al-Sana'ani, "Choudhry and Taimour - Followers of the Boarderless Loyality," Inspire 4 (2010). 
writings of $A Q$. However, they do also not condemn it. This is interesting, because $A Q$ in its ideological writings often criticizes IS' brutality. IS explains carefully in their ideological writings why it is legal according to the Islamic law, sharia, to enslave women.

In August 2014, IS attacked the Sinjar mountain in Iraq and enslaved thousands of Yazidi women. The Yazidis believe in one God and seven angels, who are ruled by the angel Melek Taus. Several Christian and Muslim groups call the Yazidis "devil worshipers" because their teaching about Malik Taus has similarities with Islamic and Christian traditions about the devil. Eyewitness accounts from the Yazidi women who have escaped from IS show that IS either gave the women away as gifts to local or foreign IS fighters or systematically sold them. ${ }^{22}$ Local IS commanders instructed the IS' fighters to inspect and choose the women to "marriage." The women were then forced to marry fighters, where they experienced brutal sexual abuse.

Dabiq has published two articles where IS, with references to religious writings, explains why it was a religious duty to enslave the Yazidis. The first text argues that the Sharia students of the caliphate have decided that the Yazidis are mushrikin, idolaters. ${ }^{23}$ They are quoting the Quran, which tells that mushrikin either should be killed or taken capture. The text argues that Muslims will be responsible for their lacking ability to kill the idolaters, primarily the men, on the Day of the Judgement. The women on the other hand are supposed to be enslaved. Slavery, especially if a slave woman gives birth to her owner's child, is one of the signs that the Day of the Judgement is approaching. Apocalyptic stories, signs on the end of the world, are in general an important part of IS' ideology. Several famous Islamic theologians, among them Ibn Rajab al-Hanbali, are quoted to explain that if women give birth to their owner's child, then the child will become free and obtain the same status as his father. The slavery is therefore a way to exterminate the Yazidis and ensure that their offspring born in slavery become true Muslim believers. It is essential to mention that several witness accounts indicate that the Yazidi women have been forced to take contraceptives to avoid pregnancy. This shows a difference in IS' ideological perspectives and what is actually taking place.

Dabiq argues that the absence of slavery in the present world has caused men to commit sins. Men who do not have the possibility to marry are encircled by temptations. If a man enslaves a woman as a concubine, the relationship becomes legal. The article concludes that slavery is an important aspect of the law of Sharia. The once not supporting this do not recognize the law of Sharia and in this way, they are apostate from Islam. A second article in Dabiq

22 UNHRC, Report of the Office of the United Nations High Commissioner for Human Rights on the Human Rights Situation in Iraq in the Light of Abuses Committed by the so-Called Islamic State in Iraq and the Levant and Associated Groups A/HRC/28/1 (13 March 2015).

23 "The Revival of Slavery Before the Hour," Dabiq 4 (October 2014): 14-17, available at http://www.danielpipes.org/rr/2014-10-dabiq.228.pdf (accessed October 26, 2016). 
tries to convince the reader that Saby, enslaving infidels through war, is the only right way. ${ }^{24}$ This is likely in order to answer the massive critique the group has received caused by the female slaves, also from IS' own supporters. Dabiq refers to the media sources of the Kuffar, which call the slavery rape. Through not defining what IS means by "kuffar," they open up for enslaving all prisoners of war. The magazine argues that important historical figures in Islam, for instance the Prophet Mohammed, enslaved women as concubines. They also claim that slave-women possess some rights, for instance it is illegal to separate a child from the mother. Dabiq argues that the main reason for enslaving women is to save them from infidelity and they wish that the women should find the right Islam. They mention several examples of Yazidi women who have converted. This is therefore a way to expand Islam as a religion and to exterminate the worshippers of the devil.

Through using theological arguments, IS can convince its audience that they serve the cause of God through enslaving the Yazidi women. The slavery will not strike the European Muslim female IS recruits, because they are true Muslims. It is illegal to enslave Muslims. IS' way of depicting Yazidi women as the slave master's property likely attracts men to the group, who do not have economical possibilities to marry in the normal way.

\section{AQ and the Islamic State's Perspectives on Women}

This article has compared the way IS and AQ position women in their ideological writings. Both movements share the perspective that women's main task is to be a good housewife, who is supposed to support her husband in armed Jihad and raise her sons in the faith. In this way he will be willing to fight to advance the case of Islam. However, $A Q$ and IS have different perspectives on women as migrants. In contrast to IS, which emphasizes that women have both a duty and right to be a migrant, $\mathrm{AQ}$ claims that migration is a man's task. For IS, female migrants play an essential role in the group's territorial state building project.

None of the movements essentially wish that women should play a role as fighters. However, there are exceptions. In their propaganda materials, both movements have glorified women who have conducted terror attacks. However, they both emphasize that Jihad is not mandatory for women. Female terror attacks are used as an incitement for men to conduct the same. AQ in Iraq also employed female suicide bombers during a time-period when the movement was deeply weakened and women had other possibilities to conduct attacks comparing to men. This shows that the ideology of $A Q$, which originally forbids women from taking part in combat, is willing and able to adjust to local needs. Despite that AQ in Iraq was the predecessor to today's IS, there are no examples of female IS suicide bombers in Syria and Iraq. Neither are there ex-

24 Umm Sumayyah al-Muhajirah, "Slave Girls or Prostitutes," Dabiq 9 (May-June 2015): 44-49. 
amples that women in the IS territory play a role in operative fighting. However, non-married women participate in IS' morality police. An explanation for this is that presently women serve IS' fight best through contributing to building the new caliphate as wives and mothers. This need can change in the future, if IS loses its territorial foothold in Syria and Iraq. It can open up for women in the future serving the caliphate best through, for instance, being suicide bombers.

The greatest difference between IS and AQ is the man's right to enslave women. While IS uses theological arguments to defend that it is correct to enslave women they define as infidels, AQ is not mentioning the topic. In its propaganda materials, IS emphasizes that slavery is an important principle of the Sharia law. The stories about female sex slaves undoubtedly play an important role in IS' own recruitment strategy. IS' positioning of women as potential slaves does therefore not necessarily conflict with women's role as a virtuous wife. The goal with both roles is that women give birth to new inhabitants of the caliphate, and that the caliphate expands.

By positioning the Yazidis as devil worshippers, which good Muslims according to IS' ideology have a duty to eradicate, IS can convince its supporters that it is important to enslave them. A female Yazidi slave will hopefully convert and her children will become Muslims. In this way, IS will be able to exterminate devil worshippers. This message is reinforced by that female slaves also play a part in IS' apocalyptical stories about the Day of the Judgement. However, a good Sunni Muslim woman can only play the virtuous housewife role. It is illegal to enslave a Muslim woman. It is the woman's duty as a good Muslim to emigrate to the caliphate, where she is given an important role in building up the new Utopian society. These factors explain why European Muslim women voluntarily choose to join IS, a group feared for committing brutal sexual violations against women.

\section{About the Author}

Andrea Aasgaard holds an MA in Middle Eastern Studies from Lund University, Sweden. She is trained as a language officer in Arabic and has previously worked as a political analyst for the Norwegian Armed Forces and as a student assistant at the Danish Institute for International Studies. 